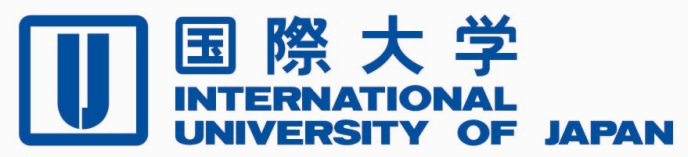

Economics \& Management Series

EMS-2012-03

\title{
Bank Risk and Non-Interest Income Activities in the Indonesian Banking Industry
}

\author{
Wahyu Yuwana Hidayat \\ Bank Indonesia
}

Makoto Kakinaka

International University of Japan

\author{
Hiroaki Miyamoto \\ International University of Japan
}

April 2012

IUJ Research Institute

International University of Japan

These working papers are preliminary research documents published by the IUJ research institute. To facilitate prompt distribution, they have not been formally reviewed and edited. They are circulated in order to stimulate discussion and critical comment and may be revised. The views and interpretations expressed in these papers are those of the author(s). It is expected that the working papers will be published in some other form. 


\title{
Bank Risk and Non-Interest Income Activities in the Indonesian Banking Industry
}

\author{
Wahyu Yuwana Hidayat ${ }^{*}$ \\ Makoto Kakinaka ${ }^{\dagger}$ \\ Hiroaki Miyamoto ${ }^{\ddagger}$
}

\begin{abstract}
The recent trend of product diversification in the Indonesian banking industry underscores the importance of non-interest income activities. This study examines the relationship between product diversification and bank risk over the period of 2002-2008. Our analysis shows clear evidence that the effect of product diversification on bank risk depends highly on the bank's asset size. Specifically, the degree of product diversification is negatively associated with bank risk for small-sized banks. Conversely, the degree of product diversification is positively related to bank risk for large-sized banks. This finding suggests that deregulation encouraging banks to become more involved in non-traditional activities may have an adverse effect on the overall banking system where large-sized banks are playing a significant role in Indonesia.
\end{abstract}

Keywords: Bank risk; Product diversification; Non-interest income activities

\footnotetext{
* Balance of Payment Bureau, Directorate of Economic and Monetary Statistics, Bank Indonesia, Jl. M.H. Thamrin No.2, Jakarta 10350, Indonesia (tel: 62-21-3818325, fax: 62-21-3800134, e-mail: wyuwana@bi.go.id).

† Corresponding Author, Graduate School of International Relations, International University of Japan, 777 Kokusai-cho, Minami-Uonuma, Niigata 949-7277, Japan (tel: 81-25-779-1421, fax: 81-25-779-1421, e-mail: kakinaka@iuj.ac.jp).

‡ Graduate School of International Relations, International University of Japan, 777 Kokusai-cho, Minami-Uonuma, Niigata 949-7277, Japan (tel: 81-25-779-1464, fax: 81-25-779-1464, e-mail: hmiyamot@iuj.ac.jp).
} 


\section{Introduction}

Recent trends in the integrated world economy with intensified competition spurred on by financial deregulation in Indonesia have encouraged commercial banks to diversify the range of financial services they offer clients. Product diversification under this new environment tends to increase the share of non-interest income in profits. Non-interest income profits stems from traditional services, like checking and cash management, as well as from new financial services, like bank account management and investment banking. As the supervisory authority, one concern for Bank Indonesia is whether or not the prevalence of product diversification increases bank risk. This issue is crucial since high bank risk gives rise to banking system instability. Given this context, this study discusses the relationship between bank risk and product diversification by empirically examining a set of risk and insolvency measures based on accounting data at the individual bank level in Indonesia over the period of 2002-2008.

The diversification of income toward non-traditional activities has been crucial in offsetting the decline in traditional income since the 1997 Asian financial crisis. At the same time, Bank Indonesia has also adopted a banking policy to encourage commercial banks to diversify their income toward non-traditional activities. ${ }^{1}$ Indeed, the fee-based income ratio is now an important bank profitability indicator for Bank Indonesia. ${ }^{2}$ To evaluate this banking policy, a more careful examination is required of the relationship between non-traditional activities and bank risk. If the prevalence of product diversification helps reduce bank risk, the banking policy will improve stability and the

\footnotetext{
${ }^{1}$ Since the 1997 Asian crisis, Bank Indonesia has adopted various banking policies. These policies include the Basel II Accord, the Indonesian Banking Architecture (API), the Indonesian Financial System Architecture (ASKI), and the development of Sharia Banking (see Bank Indonesia, 2009, for the details).

2 The fee-based income ratio is one of the important indicators to determine bank's profitability, as specified in Bank Indonesia regulation, Surat Edaran (SE) No.6/23/DPNP, May 31, 2004.
} 
overall soundness of the banking system.

Many studies, most focusing on the US banking industry, examine the relationship between product diversification and bank risk (see Saunders and Walter, 1994; Kwan and Laderman, 1999, for a review). Kwast (1989), Santomero and Chung (1992), Templeton and Severiens (1992), Saunders and Walter (1994), and Gallo, Apilado, and Kolari (1996) show potential benefits of income diversification associated with the combination of US banking and non-banking activities. In contrast, studies such as Boyd and Graham (1986, 1988), Sinkey and Nash (1993), Demsetz and Strahan (1997), Roland (1997), and Kwan (1998), are inconclusive or present partial evidence supporting the notion that product diversification with non-banking activities results in increasing US bank risk.

In particular, De Young and Roland (2001), Stiroh (2004), and Stiroh and Rumble (2006) observe potential costs of product diversification by showing that non-income activities are positively related with earnings volatility in the US. This finding is due in part to a positive correlation between interest income and non-interest income. De Young and Roland (2001) also emphasize that product diversification may not reduce risk because of the relative instability of non-interest income, fixed costs associated with non-interest income activities, and large earnings fluctuations with a high degree of financial leverage associated with a lack of regulation. As for the relationship between product diversification and bank risk outside of the US, a study by Lepetit, Nys, Rous, and Tarazi (2008) on European banks for the period 1996-2002 finds that an expansion of their income into non-interest activities increased bank risk, mainly due to commission and fee activities rather than trading activities.

For the Indonesian banking industry, a risk supervision approach is attractive to policymakers who desire a sound banking system and there are several studies related to 
risk in the Indonesian banking system. For example, Santoso (1998) examines the determinants of problem banks in Indonesia. Zulverdi, Gunadi, and Pramono (2007) study banks' behavior in portfolio selection and its impact on the effectiveness of monetary policy. However, to the best of our knowledge, no extensive study has examined how product diversification relates to bank risk in Indonesia. Thus, this study is a first attempt to better understand this important issue in the Indonesian banking industry.

Following the methodology of Lepetit, Nys, Rous, and Tarazi (2008), this study empirically investigates the relationship between non-interest income activities and bank risk by utilizing alternative ways to measure bank risks based on income structure over the period of 2002-2008. This analysis also examines how the relationship is associated with bank size. Since fixed costs associated with fee-based financial services may enable large-sized banks to take a more aggressive position on non-interest services than small-sized banks, bank size might influence a banks' behaviour in regards to non-interest income activities. In this study, to better understand the role of non-interest income activities, non-interest income is divided into two components: trading activities and commission and fee activities. Indonesian commercial bank annual report data is used and covers year-end balance sheets and income statements for 112 banks.

The analysis shows that bank size is a crucial factor determining how non-interest income activities are associated with bank risk. More precisely, a higher reliance on non-interest income activities entails a lower level of bank risk for relatively small-sized banks but entails a higher level of bank risk for relatively large-sized banks. The large-sized bank observation is consistent with the results of Kwan (1998), De Young and Roland (2001), Stiroh (2004), and Lepetit, Nys, Rous, and Tarazi (2008) in that non-banking activities increased bank risk. Furthermore, our results of size-dependent 
responses of bank risk for small-sized banks are in contrast to those of Lepetit, Nys, Rous, and Tarazi (2008) in that the positive link between non-interest income and bank risk is more significant for small-sized banks.

The remainder of this paper is organized as follows. Section 2 introduces the empirical methodology and data with several measures of bank risks, including insolvency risk. Then the empirical results are presented and show the relationship between non-interest income activities and bank risk. In particular, we focus on how the relationship varies in response to the relative asset size of banks. Section 3 offers concluding remarks with several implications related to banking policy.

\section{Empirical Analysis}

This subsection examines the relationship between product diversification and bank risk in the Indonesian commercial banking industry. ${ }^{3}$ To capture the degree of product diversification of each bank, the average ratio of net non-interest income to net operating income (NNII) is used from each bank's income statements of annual accounting data from 2002 to 2008 . Net operating income is the sum of net interest income and net non-interest income. Net non-interest income is computed as revenues from commissions and fees and from foreign exchange plus gains on investment in securities minus losses on investment in securities and foreign exchange transactions. Net interest income stems from traditional banking activities, while net non-interest income stems from non-traditional activities.

\footnotetext{
3 According to the Indonesian banking law, banking institutions are classified into commercial and rural banks. Commercial banks differ from rural banks in that the latter do not involve directly in the payment system with some restrictions on operational areas. In terms of the operational definition, banks in Indonesia are classified into non-Sharia and Sharia-based principle commercial banks. The Sharia principle is the agreement, based on the Islamic principle, between banks and counterparts to deposit with and lend to each other (Indonesia Banking act No.7, 1992, as revised by Act No.10, 1998).
} 
Stiroh (2004) and others regard non-interest income activities as a measure of the degree of non-banking activities or product diversification. Furthermore, as a product diversification measure for each bank, Stiroh (2004), De Young and Roland (2001), and Lepetit, Nys, Rous, and Tarazi (2008) divide net non-interest income into two components: the average ratio of net fee and commission income to net operating income (COM) and the average ratio of net trading income to net operating income (TRAD). This decomposition of non-interest income may be appropriate for the analysis of risk with implications for different types of financial products.

Concerning bank risk, we follow the analysis in Lepetit, Nys, Rous, and Tarazi (2008) and consider three standard measures of risk for each bank. The three standard measures, which can be calculated from annual accounting data, are the standard deviation of return on equity (SDROE), the standard deviation of return on assets (SDROA), and the average ratio of loan loss provisions to net loans (LLP) over the sample period. To capture insolvency risk for each bank, annual accounting data is used to calculate the Z-score (ADZ) which indicates the probability of bank failure (see Boyd and Graham, 1986):

$$
\mathrm{ADZ}=\frac{1+\mathrm{ROE}}{\mathrm{SDROE}}
$$

where ROE is the average return on equity over the sample period.

Annual reports for Indonesian commercial banks are used to construct the cross-sectional data for each bank on average and a standard deviation over the sample period (2002-2008). The annual reports provided by Bank Indonesia cover year-end balance sheets and income statements for 112 banks. ${ }^{4}$ We exclude banks that liquidated or

\footnotetext{
${ }^{4}$ Due to the unavailability of quarterly data for all sample banks, the sample used for our analysis is annual data from the bank account information over the period of 2002-2008, so that there are only 7 observations available in calculating bank risk measures, SDROE, SDROA, and ADZ. Although we admit that the current analysis may suffer from substantial small sample biases, current analysis would
} 
merged after 2002 from our sample. ${ }^{5}$

\subsection{Some Preliminaries}

As a preliminary investigation, this subsection first examines bank characteristics and bank risk by dividing the whole sample into two groups: large- and small-sized banks based on asset size. Then we check the relationship between bank risk and non-interest income by dividing the sample into two groups: high and low levels of non-interest income activities.

Table 1 presents descriptive statistics of all banks - large and small banks. Large banks include those that have assets greater than 1 trillion rupiah. Small banks include those that have assets smaller than 1 trillion rupiah. ${ }^{6}$ First, large banks exhibit a high profitability with a high return on equity (ROE) and a high return on assets (ROA) compared to small banks. Second, small banks show a high ratio of equity to total assets (EQUITY) when compared to large banks. Third, most relevant to this study, net non-interest income to operating income (NNII) is higher for large banks than small banks. This implies that non-banking activities, including fee and commission income and trading income, are relatively important for large banks compared to small banks. Fourth, concerning the risk measures, large banks have higher bank risk (SDROE and LLP), while small banks have higher insolvency risk (smaller ADZ).

provide some important implications about the relationship between non-interest income activity and bank risk.

${ }_{5}$ As of 2009, there were 121 commercial (4 state owned banks and 117 private banks) and 2,296 rural banks in Indonesia. The banking industry dominates other financial industries with around $80 \%$ of total financial assets (Bank Indonesia Financial Stability Review No.14, March 2010, page 23-24). We exclude PT Bank Artamedia, PT Bank Universal, PT Bank Prima Express, and PT Bank Patriot merged and became PT Bank Permata, Tbk. The same treatment is also given to some banks due to incomplete data such as PT Bank Rabobank, Bank of China, PT Bank Capital Indonesia, and PT Bank Harta.

${ }^{6}$ The cutoff asset size of 1 trillion rupiah may be considered somewhat arbitrary. However, this cutoff asset size, which divides all banks into the two groups, could be a publicly acceptable value as well as a simple value for our preliminary analysis in this study. In our sample, there are 76 large banks and 36 small banks. 
Table 2 shows various bank characteristics and risk measures for each of the two groups that are classified by the level of non-interest income activities. The group of banks with a high level of non-interest income activities are those where the value of NNII is higher than the median. Conversely, the group of banks with a low level of non-interest income activities are those where the value of NNII is lower than the median. A similar classification applies to the case of COM and TRAD to examine bank characteristics in relation to fee-based and trading activities, respectively. The results are summarized as follows.

First, banks with a high level of NNII are associated with low ratios of loans and deposits to assets (LOAN, DEPO) and a high capital ratio (EQUITY). These banks are less dependent on traditional intermediation activities with less capital leverage. Second, banks with a high level of NNII are associated with large size total assets (TA). This implies that large banks tend to intensify product diversification. De Young and Roland (2001) posit that a possible reason may be that non-interest income activity requires significant fixed costs. Third, most relevant to this study, the profitability measures, ROE and ROA, suggest that banks with a low level of NNII appear to be more profitable than those with a high level of NNII. Fourth, concerning the relationship between bank risks and non-interest income activities, the banks with a higher NNII display higher bank risks (SDROE, SDROA, and LLP) and higher insolvency risk (smaller ADZ). In sum, these findings seem to be consistent with previous results from univariate mean tests by Lepetit, Nys, Rous, and Tarazi (2008) in that non-interest income is positively associated with bank risk and insolvency risk for European banks.

\subsection{Model Specification}


The previous subsection examined the relationship between bank risks and non-interest income activities by simply comparing the average of key variables for different groups. This subsection investigates more precisely the above relationship using multivariate regression analysis. In particular, we discuss how bank risks are associated with product diversification in relation to bank size. Modifying the model of Lepetit, Nys, Rous, and Tarazi (2008), we estimate the model:

$$
R I S K_{i}=\beta_{0}+\beta_{1} P D_{i}+\beta_{2} P D_{i} \times \ln \left(T A_{i}\right)+\beta_{3} \ln \left(T A_{i}\right)+\sum_{h=1}^{H} \gamma_{h} X_{h i}+\varepsilon_{i},
$$

where $R I S K_{i}$ is the average value of risk measure for bank $i$ over the sample period, and $P D_{i}$ is the average value of the measure of product diversification for bank $i$. The model takes three bank risks (SDROE, SDROA, and LLP) and insolvency risk (ADZ) as bank risk measures. The model also uses three measures of non-interest income activities for each bank (NNII, COM, and TRAD) to capture the degree of product diversification. In addition, $\ln \left(T A_{i}\right)$ is the natural logarithm of the average value of total asset for bank $i$, which captures the size effect, and $X_{h i}$ 's are the average values of other control variables that are expected to affect risk measure.

The other control variables in the model include return on equity (ROE), the annual growth rate of total assets $(\triangle \mathrm{LOG}(\mathrm{TA}))$, the ratio of equity to total assets (EQUITY), the ratio of loans to deposits (LDR), and the dummy variable which takes unity for listed banks in the Indonesia Stock Exchange and zero for non-listed banks (Listed). ${ }^{7}$ ROE captures bank profitability. $\triangle$ LOG(TA) represents the effects of growth strategies pursued by Indonesian banks after the 1997 Asian crisis and the implementation of a Single Presence policy by Bank Indonesia. ${ }^{8}$ EQUITY, which approximates the capital

\footnotetext{
${ }_{8}^{7}$ In our sample, there are 15 listed banks.

${ }^{8}$ Single Presence is a condition where a party only becomes a Controlling Shareholder in 1 (one) Bank
} 
ratio, in addition to LDR, captures the leverage effect. All variables except for the dummy variable are the average value for each bank from 2002-2008.

One crucial aspect of the model is the inclusion of the interaction term with the measure of product diversification and asset size, $P D_{i} \times \ln \left(T A_{i}\right)$. The interaction term captures bank risk in terms of the degree of product diversification in relation to asset size. Lepetit, Nys, Rous, and Tarazi (2008) evaluate the role of asset size for European banks by dividing the whole sample into two groups - large and small banks. Instead of this classification, our study examines the role of asset size by including the interaction term in the model. Differentiating equation (1) with $P D_{i}$ yields:

$$
\frac{\partial R I S K_{i}}{\partial P D_{i}}=\beta_{1}+\beta_{2} \ln \left(T A_{i}\right)
$$

which captures how bank risk is associated with the degree of product diversification in relation to asset size.

\subsection{Results}

Table 3 shows the estimated results. Without the interaction term, $P D_{i} \times \ln \left(T A_{i}\right)$, the result shows that the coefficients on NNII are insignificant for all risk measures. That is, non-interest income activities or product diversification appear to be independent of bank and insolvency risks. However, with the interaction term in the model, non-interest income activities have an effect on bank and insolvency risks, except for the regression with SDROA as a dependent variable. For the regression with SDROE and LLP as a dependent variable, the coefficients on NNII are significantly negative, and those on the interaction term are significantly positive. For the regression with ADZ as a dependent variable, the 
coefficient on NNII is significantly positive, and that on the interaction term is significantly negative. These results suggest that the effect of product diversification on bank and insolvency risks is highly dependent on the banks' asset size. The degree of product diversification is negatively associated with bank and insolvency risk for small-sized banks, while the degree of product diversification is positively related to bank and insolvency risks for large-sized banks.

The results of the size-dependent link between product diversification and bank risk in Table 3 illustrates the critical role of asset size and the differential directional effect of product diversification on bank risks. For the SDROE equation, the critical level of the $\log$ of total assets is $\log (\mathrm{TA})=\frac{3.517}{0.515}=6.13$. Product diversification reduces bank risk for banks with a TA less than 459 billion rupiah, while it increases bank risk for banks with a TA larger than 459 billion rupiah. ${ }^{9}$ Similarly, for the LLP equation, the critical level of the $\log$ of total assets is $\log (\mathrm{TA})=\frac{0.248}{0.046}=5.39$. Product diversification reduces bank risk for banks with a TA less than 219 billion rupiah, while it increases bank risk for banks with a TA larger than 219 billion rupiah. For the ADZ equation, the critical level of the log of total assets is $\log (\mathrm{TA})=\frac{129.826}{21.392}=6.07$. Product diversification reduces insolvency risk for banks with a TA less than 433 billion rupiah, while it increases insolvency risk for banks with a TA larger than 433 billion rupiah.

For the robustness check, Table 4 illustrates the estimation results without the interaction term, $P D_{i} \times \ln \left(T A_{i}\right)$, for each of the two subsamples (small-sized and large-sized banks), which are classified in Table 1. Although some coefficients on NNII are not significant, it appears that NNII is negatively related to risk measures for the

\footnotetext{
${ }^{9}$ As of November 2011, 459 billion rupiah is equivalent to about 51 million US dollar.
} 
subsample of small-sized banks, while NNII is positively related to risk measures for the subsample of large-sized banks. Thus, these results in Table 4 provide some evidence of the partial supports for the results in Table 3.

A possible explanation of why the relationship between product diversification and bank risk depends on the asset size is as follows. Product diversification to non-interest income activities entails benefits and costs in terms of bank risk. One important benefit is to reduce risk through product diversification, similar to the logic of portfolio diversification. On the other hand, as mentioned in De Young and Roland (2001), a cost may be the relative instability of non-interest income compared to interest income. Given the above argument, the balance of benefit and cost determines the positive or negative relationship between product diversification and bank risk.

Our empirical results suggest that in terms of bank risk, the cost of instability of non-interest income dominates the benefit associated with income diversification for relatively large-sized banks. The opposite is true for relatively small-sized banks. Table 1 shows that large-sized banks are characterized by a large average ratio of net non-interest income to net operating income (NNII). As asset size becomes larger, banks tend to engage more aggressively in non-interest income activities, i.e., large-sized (small-sized) banks tend to involve more (less) non-interest income activities. Thus, the negative impact of an unstable NNII becomes more significant for large-sized banks than for small-sized banks, so that it may dominate the positive impact of income diversification for large-sized banks. Our observations for the Indonesian banking industry is different from the results of Lepetit, Nys, Rous, and Tarazi (2008) in the European banking industry whereby the positive link between product diversification and bank and insolvency risk is more significant for small-sized banks. 
Concerning the results of other control variables in Table 3 , the coefficients on Listed, $\triangle \mathrm{LOG}(\mathrm{TA})$, and LDR are insignificant for all models. This finding implies that bank risks appear not to be related to asset growth, the ratio of loans to deposits or whether the bank is listed on the Indonesia Stock Exchange. On the other hand, the results show partial support for the positive link between bank profitability and risk. The coefficients on ROE in the SDROE and ADZ equations are all significant, although those in the SDROA and LLP equations are insignificant. Moreover, the coefficients on EQUITY in the SDROA and LLP equations are significantly positive. This finding implies that the capital ratio is positively related to bank risk in terms of ROA fluctuation and loan loss provisions.

For a further investigation of the relationship between product diversification and bank risk in relation to bank size, we divide non-interest income into trading activities and commission and fee activities. These activities are considered alternative measures of product diversification based on the work of Lepetit, Nys, Rous, and Tarazi (2008). Table 5 presents the results for the case where the average ratio of net commission and fee income to net operating income $(\mathrm{COM})$ and the average ratio of net trading income to net operating income (TRAD) represent product diversification, instead of NNII in Table 3. For the models without the interaction term, the coefficients on COM are significantly positive in the SDROE and LLP equations and significantly negative in the ADZ equation. On the other hand, the coefficient on TRAD is significantly positive only in the LLP equation. Taken together, these results suggest that commission and fee activities could intensify bank risk while the impact of trading activities on bank risk is less clear. The intensified risk associated with commission and fee activities might support the finding that earnings volatility of these activities is relatively high.

Furthermore, once the interaction terms, $C O M * \log (T A)$ and TRAD* $\log (T A)$, 
are introduced in the models, the results become somewhat complicated, as shown in Table 5. In the SDROA, LLP and ADZ equations, the coefficients on COM, TRAD, and the two interaction terms, COM*Log(TA) and TRAD*Log(TA), are less significant, although the coefficient on $\mathrm{COM}^{*} \log (\mathrm{TA})$ in the SDROA equation is negative at the $10 \%$ significance level. However, the SDROE equation shows the opposite signs for COM and TRAD (i.e., the coefficients on $\mathrm{COM}$ and $\mathrm{COM}^{*} \log (\mathrm{TA})$ are respectively positive and negative while those on TRAD and TRAD* $\log (\mathrm{TA})$ are respectively negative and positive). The impact of a rise in commission and fee activities on bank risk in terms of SDROE (earnings volatility) is positive particularly for small-sized banks. Yet, its impact decreases and becomes negative as the asset size increases. In contrast, the impact of a rise in trading activities on bank risk is negative in terms of SDROE, but its impact diminishes and becomes positive with a rise in the asset size.

Regarding other control variables in Table 5, the results are qualitatively similar to those in Table 3. The coefficients on $\triangle \mathrm{LOG}(\mathrm{TA})$ and LDR are insignificant so that bank risks are not associated with asset growth or with the ratio of loans to deposits. On the other hand, the coefficients on ROE in the SDROE and ADZ equations are significant. Therefore, bank profitability is positively related to bank risk. Moreover, the significant coefficients on EQUITY in the SDROA and LLP equations imply that the capital ratio is positively related to bank risk in terms of the ROA fluctuation and loan loss provisions.

\section{Conclusion}

Financial stability, particularly after the Asian financial crisis, is a key issue for financial regulators, including central banks and also all financial institutions. To achieve financial 
stability, Bank Indonesia highly prioritizes the effectiveness and efficiency of bank supervision by applying the twin approaches of compliance-based supervision (CBS) and risk-based supervision (RBS). CBS stresses the monitoring of bank compliance and refers to the past banking conditions. The primary objective is that each bank operates properly in compliance with prudential banking principles. In contrast, RBS represents a forward-looking approach to supervision which allows the supervisory authority to keep greater room for proactive actions (see Bank Indonesia, 2009).

Given this environment, this study has examined risk implications of the recent trends regarding diversified financial products that provide banks with additional sources of income in the Indonesian banking industry. Our study provides clear evidence that product diversification causes small-sized banks to reduce bank risk successfully but magnifies bank risk for large-sized banks. The results in the Indonesian banking industry is different from those of Lepetit, Nys, Rous, and Tarazi (2008) in the European banking industry whereby the positive link between product diversification and bank and insolvency risk is more significant for small-sized banks. Furthermore, the results from our models demonstrate, to different extents, that greater reliance on commission and fee activities is associated with higher bank risk in terms of earnings volatility particularly for small-sized banks.

Our results have important policy implications related to bank supervision from the perspective of bank risk in the Indonesian banking industry. The argument that product diversification increases bank risk for large-sized banks suggests that deregulation practices that encourage banks to pursue non-traditional activities may adversely affect the banking system due to the sizeable market share of large-sized banks. Thus, the financial authorities, including Bank Indonesia, must carefully monitor large banks' behaviour 
related to various bank and insolvency risks, such as credit risk, market risk, liquidity risk, and operational risk, under the Basel II Accord framework. In particular, strict monitoring policies to reduce bank risk might be needed for large-sized banks.

It should be noticed that our regression analysis has some limitations. For example, we have focused on the discussion about how product diversification affects risk measures in relation to banks' asset size. However, when we examine the role of product diversification, the analysis should take into account not only bank risk but also bank profitability or efficiency due to their close interactions. More careful and extensive examination about the relationship among product diversification, bank risk, and bank profitability should be conducted to understand the in-depth feature of the Indonesian banking industry. Next, our empirical analysis is based on averaged data over the small sample period from 2002 to 2008 . The small sample may cause substantial sample biases in our estimation results. Moreover, the use of averaged data cannot enable us to capture the dynamic aspects, including structural changes, although the Indonesian banking industry has been developing rapidly with continuous changing environments.

Regarding future research directions, this initial study can also be extended in several interesting directions. One possibility is to examine the relationship between income structure and bank risk in the rural banking industry as rural banks have been playing an increasingly important role in rural development. Generally, rural banks have monopoly power due to the fact that people experience some difficulty in accessing funds in their regions where there are few commercial banks. Appropriate regulatory policies for rural banks might be different from those for urban commercial banks. Another direction is to incorporate market-based risk measures into our discussion. The market-based risk measures can supplement traditional analysis, which is based on financial accounting 
statements, with forward-looking information from security prices. Most large banks are now listed on the Indonesian Stock Exchange, and thus face regulatory monitoring and the daily scrutiny of stock market participants. Finally, to date, there has been no empirical and theoretical work performed on these important issues in the Indonesian banking industry. Although we admit that it is challenging to verify empirically these important problems due to a lack of data, we hope that the results derived in this paper can be a good starting point and benchmark to test the relationship between product diversification and bank risk in Indonesia.

\section{References}

Bank Indonesia (2009). Indonesian banking booklet 2009. Directorate of Bank Licensing and Banking Information, Bank Indonesia.

Boyd, J.H., and Graham, S.L. (1986). Risk, regulation, and bank holding company expansion into non-banking, Quarterly Review, Federal Reserve Bank of Minneapolis.

Boyd, J.H., and Graham, S.L. (1988). "The profitability and risk effects of allowing bank holding companies to merge with other financial firms: A simulation study," Quarterly Review, Federal Reserve Bank of Minneapolis.

Demsetz, R., and Strahan, P. (1997). Diversification, size, and risk at bank holding companies. Journal of Money, Credit and Banking, 29, 300-313.

De Young, R., and Roland, K. (2001). Product mix and earnings volatility at commercial banks: Evidence from a degree of total leverage model. Journal of Financial Intermediation, 10, 54-84. 
Gallo, J., Apilado, V., and Kolari, J. (1996). Commercial bank mutual fund activities: Implications for bank risk and profitability. Journal of Banking and Finance, 20, $1775-1791$.

Kwan, S.H. (1998). Securities activities by commercial banking firms' Section 20 subsidiaries: Risk, return, and diversification benfits. In Proceeding from a Conference on Bank Structure and Competition, Federal Reserve Bank of Chicago, May, 531-552.

Kwan, S.H., and Laderman, E.S. (1999). On the portfolio effects of financial convergence: A review of the literature. Economic Review, 1999-2, Federal Reserve Bank of San Francisco, 18-31.

Kwast, M. (1989). The impact of underwriting and dealing on bank returns and risks. Journal of Banking and Finance, 13, 101-125.

Lepetit, L., Nys, E., Rous, P., and Tarazi, A. (2008). Bank income structure and risk: An empirical analysis of European banks, Journal of Banking and Finance, 32, $1452-1467$.

Roland, K. (1997). Profit persistence in large U.S. bank holding companies: An empirical investigation, Office of the Comptroller of the Currency, Economics Working Paper, WP97-2.

Santomero, A.W., and Chung, E.-J. (1992). Evidence in support of broader banking powers. Financial markets, institutions, and instruments, 1, 1-69.

Santoso, W. (1998). The determinants of problem banks in Indonesia: An empirical study, Directorate of Banking Research and Regulations, Bank of Indonesia.

Saunders, A., and Walter, I. (1994). Universal banking in the United States: What could we gain? What could we lose? Oxford University Press, New York. 
Sinkey, J.F., Jr., and Nash, R.C. (1993). Assessing the riskiness and profitability of credit-card banks, Journal of Financial Services Research, 7, 127-150.

Stiroh, K. (2004). Diversification in banking: Is non-interest income the answer? Journal of Money, Credit and Banking, 36, 853-882.

Stiroh, K., and Rumble, A. (2006). The dark side of diversification: The case of US financial holding companies. Journal of Banking and Finance, 30, 2131-2161.

Templeton, W.K., and Severiens, J.T. (1992). The effect of nonbank diversification on bank holding company risk. Quarterly Journal of Business and Economics, 31, 3-16.

Zulverdi, D., Gunadi, I., and Pramono, B. (2007). Bank portfolio model and monetary policy in Indonesia, Journal of Asian Economics, 18, 158-174. 
Table 1

Descriptive Statistics

\begin{tabular}{lccccccccccccccc}
\hline & TA & LOAN & DEPO & EQUITY & NNII & COM & TRAD & ROE & ROA & SDROE & SDROA & LLP & ADZ \\
\hline All banks (112 banks) & & & & & & & & & \\
\hline Mean & 13,276 & 0.523 & 0.740 & 0.150 & 0.086 & 0.067 & 0.018 & 0.214 & 0.023 & 0.128 & 0.016 & 0.039 & 22.083 \\
Std & 36,348 & 0.162 & 0.132 & 0.098 & 0.182 & 0.100 & 0.215 & 0.177 & 0.023 & 0.308 & 0.040 & 0.033 & 15.873 \\
Max & 270,500 & 0.821 & 0.910 & 0.603 & 0.824 & 0.841 & 0.561 & 1.001 & 0.065 & 3.093 & 0.360 & 0.187 & 98.009 \\
Min & 43 & 0.089 & 0.348 & 0.027 & -1.182 & 0.000 & -2.023 & -0.206 & -0.144 & 0.011 & 0.001 & 0.009 & 0.647 \\
\hline Large banks (76 banks): Total Assets $>1$ trillion rupiah & & & & & & \\
\hline Mean & 19,342 & 0.517 & 0.737 & 0.126 & 0.117 & 0.074 & 0.044 & 0.264 & 0.026 & 0.138 & 0.014 & 0.043 & 23.010 \\
Std & 42,887 & 0.158 & 0.129 & 0.071 & 0.131 & 0.073 & 0.088 & 0.171 & 0.025 & 0.364 & 0.041 & 0.035 & 16.846 \\
Max & 270,500 & 0.821 & 0.910 & 0.360 & 0.576 & 0.288 & 0.525 & 1.001 & 0.066 & 3.093 & 0.360 & 0.187 & 98.009 \\
Min & 1,038 & 0.213 & 0.404 & 0.027 & -0.031 & 0.000 & -0.128 & -0.002 & -0.144 & 0.011 & 0.001 & 0.011 & 0.647 \\
\hline Small banks (36 banks): Total Assets $<1$ trillion rupiah & & & & & & & \\
\hline Mean & 472 & 0.536 & 0.745 & 0.199 & 0.019 & 0.054 & -0.035 & 0.108 & 0.016 & 0.110 & 0.019 & 0.032 & 20.124 \\
Std & 271 & 0.172 & 0.138 & 0.126 & 0.247 & 0.143 & 0.353 & 0.140 & 0.017 & 0.133 & 0.036 & 0.028 & 13.604 \\
Max & 929 & 0.808 & 0.892 & 0.603 & 0.824 & 0.841 & 0.561 & 0.557 & 0.064 & 0.571 & 0.214 & 0.156 & 74.114 \\
Min & 43 & 0.089 & 0.348 & 0.073 & -1.182 & 0.000 & -2.023 & -0.206 & -0.025 & 0.014 & 0.002 & 0.009 & 1.616 \\
\hline
\end{tabular}

Notes: 1 trillion rupiah is equivalent to about 110 million US dollar; TA = total assets (billion rupiah); LOAN = loans/total assets; DEPO = deposits/total assets; EQUITY = equity/total assets; NNII = net non interest income/net operating income; $\mathrm{COM}=$ net commission income/net operating income; TRAD $=$ net trading income/net operating income; $\mathrm{ROE}=$ return on equity; ROA = return on assets; $\mathrm{SDROE}=$ standard deviation of return on equity; $\mathrm{SDROA}=$ standard deviation of return on assets; LLP $=$ loan loss provisions/net loans; $\mathrm{ADZ}=\mathrm{Z}$-score. 
Table 2

Income Structure and Bank Characteristics

\begin{tabular}{|c|c|c|c|c|c|c|c|c|c|c|c|c|c|}
\hline & TA & LOAN & DEPO & EQUITY & NNII & $\mathrm{COM}$ & TRAD & ROE & ROA & SDROE & SDROA & LLP & ADZ \\
\hline \multicolumn{14}{|c|}{ Banks with low NNII (56 banks) } \\
\hline Mean & 6,763 & 0.537 & 0.787 & 0.130 & -0.007 & 0.031 & -0.039 & 0.228 & 0.024 & 0.084 & 0.009 & 0.026 & 23.349 \\
\hline Std & 21,512 & 0.154 & 0.081 & 0.071 & 0.160 & 0.113 & 0.271 & 0.162 & 0.017 & 0.080 & 0.008 & 0.016 & 15.548 \\
\hline \multicolumn{14}{|c|}{ Banks with high NNII (56 banks): } \\
\hline Mean & 19,789 & 0.509 & 0.693 & 0.169 & 0.178 & 0.103 & 0.075 & 0.200 & 0.021 & 0.173 & 0.022 & 0.053 & 20.816 \\
\hline Std & 46,013 & 0.170 & 0.155 & 0.116 & 0.153 & 0.071 & 0.114 & 0.191 & 0.029 & 0.426 & 0.055 & 0.040 & 16.231 \\
\hline \multicolumn{14}{|c|}{ Banks with low COM (56 banks) } \\
\hline Mean & 6,169 & 0.524 & 0.792 & 0.124 & 0.020 & 0.013 & 0.007 & 0.256 & 0.022 & 0.136 & 0.015 & 0.026 & 21.158 \\
\hline Std & 19,791 & 0.161 & 0.081 & 0.072 & 0.032 & 0.010 & 0.029 & 0.184 & 0.028 & 0.407 & 0.047 & 0.016 & 13.130 \\
\hline \multicolumn{14}{|c|}{ Banks with high COM (56 banks) } \\
\hline Mean & 20,383 & 0.521 & 0.688 & 0.175 & 0.151 & 0.122 & 0.029 & 0.172 & 0.023 & 0.122 & 0.016 & 0.053 & 23.008 \\
\hline Std & 46,603 & 0.165 & 0.151 & 0.114 & 0.238 & 0.119 & 0.303 & 0.161 & 0.018 & 0.163 & 0.030 & 0.040 & 18.284 \\
\hline \multicolumn{14}{|c|}{ Banks with low TRAD (56 banks) } \\
\hline Mean & 4,826 & 0.517 & 0.762 & 0.148 & 0.005 & 0.047 & -0.041 & 0.215 & 0.024 & 0.105 & 0.011 & 0.030 & 21.492 \\
\hline Std & 11,449 & 0.159 & 0.116 & 0.106 & 0.167 & 0.119 & 0.270 & 0.179 & 0.018 & 0.137 & 0.012 & 0.023 & 14.266 \\
\hline \multicolumn{14}{|c|}{ Banks with high TRAD (56 banks) } \\
\hline Mean & 21,727 & 0.528 & 0.717 & 0.151 & 0.166 & 0.088 & 0.078 & 0.212 & 0.022 & 0.153 & 0.020 & 0.049 & 22.673 \\
\hline Std & 48,886 & 0.166 & 0.143 & 0.090 & 0.160 & 0.074 & 0.112 & 0.177 & 0.028 & 0.415 & 0.054 & 0.039 & 17.441 \\
\hline
\end{tabular}

Notes: TA = total assets (billion rupiah); LOAN = loans/total assets; DEPO = deposits/total assets; EQUITY = equity/total assets; NNII = net non interest income/net operating income; $\mathrm{COM}=$ net commission income/net operating income; $\mathrm{TRAD}=$ net trading income/net operating income; $\mathrm{ROE}=$ return on equity; $\mathrm{ROA}=$ return on assets; $\mathrm{SDROE}=$ standard deviation of return on equity; $\mathrm{SDROA}=$ standard deviation of return on assets; $\mathrm{LLP}=$ loan loss provisions/net loans; $\mathrm{ADZ}=\mathrm{Z}$-score. 
Table 3

Estimation Results

\begin{tabular}{|c|c|c|c|c|c|c|c|c|}
\hline \multirow{4}{*}{ NNII } & \multicolumn{6}{|l|}{ Risk measures } & \multirow{2}{*}{\multicolumn{2}{|c|}{$\begin{array}{c}\text { Insolvency measure } \\
\text { ADZ } \\
\end{array}$}} \\
\hline & \multicolumn{2}{|c|}{ SDROE } & \multicolumn{2}{|c|}{ SDROA } & \multicolumn{2}{|c|}{ LLP } & & \\
\hline & -0.070 & $-3.157 * *$ & -0.003 & -0.236 & 0.025 & $-0.248^{*}$ & 1.700 & $129.826^{* *}$ \\
\hline & $(0.272)$ & (1.442) & $(0.026)$ & $(0.178)$ & $(0.019)$ & $(0.126)$ & (12.190) & (58.707) \\
\hline \multirow[t]{2}{*}{$\log (\mathrm{TA})$} & -0.114 & $-0.185^{*}$ & -0.012 & -0.017 & $0.016 * *$ & $0.010^{*}$ & 0.136 & 3.097 \\
\hline & $(0.089)$ & $(0.106)$ & $(0.011)$ & $(0.014)$ & $(0.005)$ & $(0.005)$ & $(2.096)$ & (2.311) \\
\hline \multirow[t]{2}{*}{ NNII*Log(TA) } & - & $0.515^{* *}$ & - & 0.039 & - & $0.046^{* *}$ & - & $-21.392 * *$ \\
\hline & - & $(0.230)$ & - & $(0.029)$ & - & $(0.022)$ & - & (9.362) \\
\hline \multirow[t]{2}{*}{ Listed } & 0.325 & 0.335 & 0.038 & 0.039 & -0.004 & -0.004 & -1.234 & -1.612 \\
\hline & $(0.219)$ & $(0.215)$ & $(0.028)$ & $(0.028)$ & $(0.009)$ & $(0.009)$ & (4.342) & (4.357) \\
\hline \multirow[t]{2}{*}{ ROE } & $1.099 *$ & $1.145^{*}$ & 0.109 & 0.113 & 0.006 & 0.010 & $-18.566^{*}$ & $-20.467 * *$ \\
\hline & $(0.639)$ & $(0.632)$ & $(0.083)$ & $(0.083)$ & $(0.019)$ & $(0.017)$ & $(9.852)$ & $(9.655)$ \\
\hline \multirow[t]{2}{*}{$\Delta \log (\mathrm{TA})$} & -0.741 & -0.627 & -0.070 & -0.062 & -0.011 & -0.001 & 51.742 & 47.028 \\
\hline & $(0.708)$ & $(0.672)$ & $(0.085)$ & $(0.080)$ & (0.089) & (0.089) & $(51.401)$ & $(51.006)$ \\
\hline \multirow[t]{2}{*}{ EQUITY } & 0.490 & 0.423 & $0.156^{*}$ & $0.151 *$ & $0.171 * *$ & $0.165 * *$ & -24.119 & -21.335 \\
\hline & $(0.351)$ & $(0.363)$ & $(0.080)$ & $(0.083)$ & $(0.045)$ & $(0.046)$ & (18.653) & (19.043) \\
\hline \multirow[t]{2}{*}{ LDR } & -0.010 & -0.011 & -0.004 & -0.004 & 0.017 & 0.017 & 5.558 & 5.610 \\
\hline & $(0.058)$ & $(0.061)$ & $(0.009)$ & $(0.009)$ & $(0.018)$ & $(0.018)$ & $(5.015)$ & $(5.265)$ \\
\hline \multirow[t]{2}{*}{ Cons. } & 0.571 & $0.979 *$ & 0.046 & 0.077 & $-0.104 * *$ & $-0.068^{*}$ & 20.962 & 4.035 \\
\hline & $(0.430)$ & $(0.528)$ & $(0.058)$ & $(0.075)$ & (0.034) & $(0.036)$ & (14.067) & $(15.351)$ \\
\hline R-squared & 0.341 & 0.382 & 0.259 & 0.274 & 0.345 & 0.372 & 0.063 & 0.090 \\
\hline Number of Obs. & 112 & 112 & 112 & 112 & 112 & 112 & 112 & 112 \\
\hline
\end{tabular}

Notes: (1) ** and * indicate significance at the $5 \%$ and $10 \%$ levels, respectively. (2) Robust standard errors are in parentheses. (3) Variable definitions: NNII = ratio of net non

interest income to net operating income; $\log (\mathrm{TA})=$ logarithm of total assets; Listed = dummy variable which take the value of 1 for listed banks and 0 for non listed banks; ROE = return on equity; $\Delta \log (\mathrm{TA})=\operatorname{logarithm}$ of annual growth rate of total assets; EQUITY $=$ Equity on total assets; LDR $=$ loan to deposit; SDROE = standard deviation of the return on equity; SDROA = standard deviation of return on assets; LLP = ratio of loan loss provisions to net loans; ADZ = Z-score. 
Table 4

Estimation Results

\begin{tabular}{|c|c|c|c|c|c|c|c|c|}
\hline & \multicolumn{6}{|c|}{ Risk measures } & \multirow{2}{*}{\multicolumn{2}{|c|}{\begin{tabular}{|c|} 
Insolvency measure \\
$\mathrm{ADZ}$ \\
\end{tabular}}} \\
\hline & \multicolumn{2}{|c|}{ SDROE } & \multicolumn{2}{|c|}{ SDROA } & \multicolumn{2}{|c|}{ LLP } & & \\
\hline & Small & Large & Small & Large & Small & Large & Small & Large \\
\hline \multirow[t]{2}{*}{ NNII } & $-0.184 * *$ & $0.538^{*}$ & -0.014 & $0.065^{*}$ & -0.011 & $0.081 * *$ & 4.284 & $-19.920 *$ \\
\hline & $(0.059)$ & $(0.320)$ & $(0.009)$ & $(0.038)$ & $(0.016)$ & $(0.029)$ & $(4.776)$ & (11.949) \\
\hline \multirow[t]{2}{*}{$\log (\mathrm{TA})$} & $0.196^{* *}$ & -0.074 & $0.067 *$ & -0.009 & $0.048 * *$ & 0.008 & -9.243 & -1.627 \\
\hline & $(0.090)$ & $(0.052)$ & $(0.037)$ & $(0.006)$ & $(0.023)$ & $(0.007)$ & $(8.427)$ & (3.128) \\
\hline \multirow[t]{2}{*}{ ROE } & $-0.514^{* *}$ & $1.329 * *$ & -0.077 & 0.129 & -0.025 & 0.017 & $27.293 *$ & $-33.242 * *$ \\
\hline & $(0.188)$ & $(0.644)$ & $(0.047)$ & $(0.086)$ & $(0.029)$ & $(0.020)$ & $(13.487)$ & (12.593) \\
\hline \multirow[t]{2}{*}{$\Delta \log (\mathrm{TA})$} & $1.034 * *$ & -1.818 & 0.144 & -0.186 & 0.093 & -0.052 & -86.914 & $103.526^{*}$ \\
\hline & $(0.450)$ & $(1.125)$ & $(0.099)$ & $(0.142)$ & $(0.067)$ & $(0.120)$ & $(56.585)$ & $(54.602)$ \\
\hline \multirow[t]{2}{*}{ EQUITY } & $0.481^{*}$ & -0.603 & $0.261 * *$ & -0.035 & $0.230 * *$ & 0.100 & -11.669 & -11.527 \\
\hline & $(0.252)$ & $(0.553)$ & $(0.112)$ & $(0.065)$ & $(0.068)$ & $(0.090)$ & $(18.575)$ & $(35.235)$ \\
\hline \multirow[t]{2}{*}{ LDR } & 0.062 & 0.106 & 0.033 & 0.013 & -0.013 & 0.026 & -2.134 & 3.047 \\
\hline & $(0.085)$ & $(0.120)$ & $(0.024)$ & $(0.014)$ & $(0.022)$ & $(0.023)$ & $(10.300)$ & $(9.486)$ \\
\hline \multirow[t]{2}{*}{ Cons. } & -1.130 & 0.355 & -0.429 & 0.040 & $-0.274^{*}$ & -0.050 & 78.275 & 36.491 \\
\hline & $(0.555)$ & $(0.325)$ & $(0.234)$ & $(0.033)$ & $(0.144)$ & $(0.050)$ & $(51.535)$ & $(24.656)$ \\
\hline R-squared & 0.631 & 0.469 & 0.619 & 0.347 & 0.610 & 0.338 & 0.156 & 0.235 \\
\hline Number of Obs. & 36 & 76 & 36 & 76 & 36 & 76 & 36 & 76 \\
\hline
\end{tabular}

Notes: (1)** and * indicate significance at the 5\% and 10\% levels, respectively. (2) Robust standard errors are in parentheses. (3) Variable definitions: NNII = ratio of net non interest income to net operating income; $\log (\mathrm{TA})=$ logarithm of total asset; Listed = dummy variable which take the value of 1 for listed banks and 0 for non listed banks; ROE = return on equity; $\Delta \log (\mathrm{TA})=\operatorname{logarithm}$ of annual growth rate of total assets; EQUITY $=$ Equity on total assets; LDR $=$ loan to deposit; $\mathrm{SDROE}=$ standard deviation of the return on equity; $\mathrm{SDROA}=$ standard deviation of the return on assets; LLP = ratio of loan loss provisions to net loans; ADZ = Z-score. 
Table 5

Estimation Results

\begin{tabular}{|c|c|c|c|c|c|c|c|c|}
\hline \multirow{4}{*}{$\mathrm{COM}$} & \multicolumn{6}{|l|}{ Risk measures } & \multirow{2}{*}{\multicolumn{2}{|c|}{$\begin{array}{r}\text { Insolvency measure } \\
\mathrm{ADZ}\end{array}$}} \\
\hline & \multicolumn{2}{|c|}{ SDROE } & \multicolumn{2}{|c|}{ SDROA } & \multicolumn{2}{|c|}{ LLP } & & \\
\hline & $0.879 * *$ & $5.823 *$ & 0.067 & 0.745 & $0.086^{*}$ & -0.142 & $-41.598^{* *}$ & -99.484 \\
\hline & $(0.375)$ & $(3.377)$ & $(0.053)$ & $(0.460)$ & $(0.045)$ & $(0.310)$ & (12.564) & (97.758) \\
\hline \multirow[t]{2}{*}{ TRAD } & 0.025 & $-3.304 *$ & 0.004 & -0.380 & $0.031^{*}$ & -0.171 & -2.627 & 44.335 \\
\hline & $(0.108)$ & $(1.968)$ & $(0.016)$ & $(0.257)$ & $(0.018)$ & $(0.270)$ & (5.309) & (71.717) \\
\hline \multirow[t]{2}{*}{$\log (\mathrm{TA})$} & $-0.167^{*}$ & -0.106 & -0.016 & -0.007 & $0.013^{* *}$ & $0.010^{*}$ & 2.569 & 1.849 \\
\hline & $(0.099)$ & $(0.065)$ & $(0.013)$ & $(0.010)$ & $(0.006)$ & $(0.006)$ & $(2.066)$ & $(2.360)$ \\
\hline \multirow[t]{2}{*}{ COM*Log(TA) } & - & $-0.855^{*}$ & - & $-0.116^{*}$ & - & 0.032 & - & 10.172 \\
\hline & - & $(0.508)$ & - & $(0.069)$ & - & $(0.045)$ & - & $(15.726)$ \\
\hline \multirow[t]{2}{*}{ TRAD*Log(TA) } & - & $0.607^{*}$ & - & 0.071 & - & 0.033 & - & -8.484 \\
\hline & - & $(0.353)$ & - & $(0.045)$ & - & $(0.045)$ & - & (12.695) \\
\hline \multirow[t]{2}{*}{ Listed } & 0.335 & $0.377^{*}$ & 0.039 & 0.044 & -0.004 & -0.003 & -1.675 & -2.215 \\
\hline & $(0.212)$ & $(0.215)$ & $(0.028)$ & $(0.028)$ & $(0.009)$ & $(0.009)$ & $(4.341)$ & $(4.629)$ \\
\hline \multirow[t]{2}{*}{ ROE } & $1.241 *$ & $1.145^{* *}$ & 0.120 & 0.108 & 0.015 & 0.013 & $-25.027 * *$ & $-23.763 * *$ \\
\hline & $(0.648)$ & $(0.555)$ & $(0.086)$ & $(0.074)$ & $(0.019)$ & $(0.020)$ & (9.860) & (10.412) \\
\hline \multirow[t]{2}{*}{$\Delta \log (\mathrm{TA})$} & -1.072 & -1.086 & -0.095 & -0.101 & -0.032 & -0.013 & 66.858 & 66.606 \\
\hline & $(0.755)$ & $(0.735)$ & $(0.094)$ & $(0.093)$ & $(0.091)$ & $(0.097)$ & $(51.262)$ & (52.549) \\
\hline \multirow[t]{2}{*}{ EQUITY } & 0.329 & 0.392 & $0.144 *$ & $0.151^{*}$ & $0.160 * *$ & $0.162 * *$ & -16.753 & -17.595 \\
\hline & $(0.350)$ & $(0.347)$ & $(0.084)$ & $(0.083)$ & $(0.047)$ & $(0.049)$ & (18.810) & (18.695) \\
\hline \multirow[t]{2}{*}{ LDR } & -0.002 & -0.031 & -0.003 & -0.007 & 0.017 & 0.017 & 5.199 & 5.575 \\
\hline & $(0.058)$ & $(0.057)$ & $(0.009)$ & $(0.009)$ & $(0.018)$ & $(0.018)$ & $(4.802)$ & $(4.803)$ \\
\hline \multirow[t]{2}{*}{ Cons. } & $0.857^{*}$ & 0.515 & 0.067 & 0.020 & $-0.085 * *$ & $-0.070^{*}$ & 7.938 & 11.948 \\
\hline & $(0.488)$ & $(0.316)$ & $(0.069)$ & $(0.052)$ & $(0.037)$ & $(0.040)$ & (13.635) & (15.487) \\
\hline R-squared & 0.403 & 0.468 & 0.280 & 0.343 & 0.367 & 0.375 & 0.112 & 0.116 \\
\hline Number of Obs. & 112 & 112 & 112 & 112 & 112 & 112 & 112 & 112 \\
\hline
\end{tabular}

Notes: $(1) * *$ and $*$ indicate significance at the $5 \%$ and $10 \%$ levels, respectively. (2) Robust standard errors are in parentheses. (3) Variable definitions: COM = net commission income/net operating income; TRAD = net trading income/net operating income; $\log (\mathrm{TA})=$ logarithm of total asset; Listed = dummy variable which take the value of 1 for listed banks and 0 for non listed banks; ROE $=$ return on equity; $\Delta \log (\mathrm{TA})=\operatorname{logarithm}$ of annual growth rate of total assets; EQUITY $=$ Equity on total assets; LDR $=$ loan to deposit; $\mathrm{SDROE}=$ standard deviation of the return on equity; $\mathrm{SDROA}=$ standard deviation of return on assets; LLP $=$ ratio of loan loss provisions to net loans; $\mathrm{ADZ}=\mathrm{Z}$-score. 